\title{
THE MISERY OF WAR AS SEEN IN STEPHEN CRANE'S WAR IS KIND AND WALT WHITMAN'S DIRGE FOR TWO VETERANS
}

\author{
Luqman Nur Chandra
}

\begin{abstract}
INTISARI
Artikel ini mendiskusikan hasil penelitian terhadap dua puisi, yaitu puisi berjudul War is Kind yang ditulis oleh Stephen Crane dan Dirge for Two Veterans yang ditulis oleh Walt Whitman. Tema yang terkandung di dalam kedua puisi tersebut adalah perang.

Tujuan penelitian ini adalah untuk menggambarkan kesedihan yang disebabkan oleh perang dan untuk membandingkan cara kedua puisi tersebut di dalam mengekspresikan tema tentang perang.Pendekatan yang digunakan dalam penelitian ini adalah pendekatan objektif. Pendekatan ini dipilih karena analisis hanya berdasar kepada elemen-elemen yang ditemukan di dalam puisi. Metode yang digunakan di dalam penelitian ini adalah studi perpustakaan. Kemudian metode deskriptif diterapkan untuk menjelaskan puisi secara deskriptif melalui interpretasi tiap bait di dalam puisi.

Hasil dari penelitian ini menunjukkan bahwa kesedihan yang disebabkan oleh perang itu nyata dan mempengaruhi banyak orang di dalamnya. Baik puisi War is Kind ataupun Dirge for Two Veterans sama-sama menggambarkan tentang kematian dan kesedihan yang disebabkan oleh perang, walaupun dengan ekspresi yang sedikit berbeda. War is Kind menonjolkan ironi bahwa 'perang itu baik' untuk memunculkan kesan yang sangat buruk. Penggunaan ironi ini mencoba mempengaruhi pembaca untuk menghakimi bahwa perang sangatlah buruk. Dirge for Two Veterans juga menunjukkan bahwa kematian merupakan konsekuensi dari perang. Namun dalam puisi ini kesedihan digambarkan sebagai sesuatu yang harus bisa dihadapi walaupun menimbulkan ketakutan dan menghantui pikiran.
\end{abstract}

Kata Kunci: kesedihan, perang, kematian, ironi

\begin{abstract}
This article discusses two poems, a Stephen Crane's poem entitled War is Kind and a Walt Whitman's poem entitled Dirge for Two Veterans. These two poems are about the war.

The objectives of the study are to illustrate the misery that is caused by the war and to compare the different way's of expressing the same theme in these two poems. The approach used in this research is the objective approach. This approach is chosen because the analysis is solely based on the elements found in the poems. This paper uses the library research as the method of research. Then the descriptive method is applied to explain the poems descriptively by interpreting each stanza in the poems.

The result of the research shows that the misery which is caused by war exists and affects so many people. Both Stephen Crane's War is Kind and Walt Whitman's Dirge for Two Veterans provide us with images of death and misery that are caused by the war though in a slight different way in expressing the theme. War is Kind highlights the irony of 'war is kind' to provoke the sense of dreadfulness. By using this irony, it tries to influence the readers to judge that war is not kind at all. Walt Whitman's Dirge for Two Veterans also points out death as the consequence of the war. But in this poem, misery is described as something that should be endured though it is haunting and frightening.
\end{abstract}

Keywords: misery, war, death, irony 


\section{INTRODUCTION}

It should be understood that poetry can be written for various reasons and purposes. Some poems are written purely to entertain us while others are for the purpose of moral persuasion. "Many poems try to be both entertaining and instructive, both amusing and edifying at the same time" (Reaske 8). Some poems use irony which results from the contrast between the actual meaning of a word or statement and a suggested meaning. There is also the term sarcasm which is considered as a heavier-handed irony. Sarcasm usually sounds harsh or biting, while irony can be light, comic, and playful (Reaske 35). While some other poems are just impersonal and detached which automatically arouses certain emotional responses in the readers.

When writing a poem, there is always a theme that is provided by the poets. "Theme is the central concept developed in a poem. It is the basic idea which the poet is trying to convey and which, accordingly, he allows to direct his imagery" (Reaske 42). One of those themes is about war. According to Webster's Dictionary of the English Language, war is an open armed conflict between nations, states, or between parties in the same state, carried on by force or arms for various purposes.

In reality, war has caused so many destructions in human's life. The damage that is caused by war is very devastating. It causes massive destructions, makes people suffer from pain and violence, kills the living things in the area of war, and hurts so many innocent people. Thousands of soldiers may die worthlessly and citizens may die for unknown reasons. War in any era will always cause misery for the people who are intentionally involved in the war itself or even worse for the people who are accidentally involved in the war.

However, despite the fact that war causes destruction and misery to most people, it attracts people to get involved in it. There are people who are interested to talk and write about the theme of war. Stephen Crane and Walt Whitman are among these war-poem writers. Stephen Crane's War Is Kind talks about the theme of war in the Spanish-American War while Walt Whitman's Dirge for Two Veterans talks about the same theme in the American Civil War. Although these two poems have the same theme but each of the poems has its own characteristic in expressing the misery that is caused by the war.

This Paper discusses Stephen Crane's poem entitled War is Kind and Walt Whitman's poem entitled Dirge for Two Veterans in order to show the misery that is caused by the war and to comprehend the viewpoint of war which is portrayed in each of the poems.

In line with the objectives of this paper, the focus of examination will be the poems written by Stephen Crane entitled War is Kind and Walt Whitman entitled Dirge for Two Veterans. The analysis of this paper will be limited to the properties of the poem.

In order to achieve the objectives of this paper, the objective approach would be applied. By using objective approach, a literary work should be regarded as autonomous and should not be judged by reference to considerations beyond itself.

Objective criticism regards the work of art in isolation from all external points of reference, analyzes it as a self-sufficient entity constituted by its parts in their internal relations, and sets out to judge it solely by criteria intrinsic to its own mode of being (Abrams, The Mirror and the Lamp 26).

This paper uses the library research as the method of research. There are two types of data that are used in this paper which are primary and secondary data. The primary data consists of Stephen Crane's poem entitled War is Kind and Walt Whitman's poem entitled Dirge for Two Veterans whereas the secondary data are sources from the internet that are related to war, especially about Spanish-American war and American Civil war. To 
be able to comprehend the poems, the basic versification, the rhyme scheme, the kind of language, and other devices of the poem will be provided. Then the descriptive method is applied. It helps the writer to explain the poems descriptively by interpreting each stanza of the poems.

\section{DISCUSSION}

\section{A. War is Kind by Stephen Crane}

The subject of misery that is described in the first stanza is the maiden whose lover has died in the war. The first stanza begins with 'Do not weep, maiden, for war is kind.' The first line of the stanza gives the ironic tone of the poem, as it is difficult to imagine that war can be kind in any way. This opening line confirms that tone. It is addressed to the maiden asking her not to weep because war is kind somehow.

The next two lines tell about the lover who died in the war. 'Because the lover threw wild hands toward the sky - and the affrighted steed ran on alone,' these two lines provide the image of a dying soldier. It cannot be predicted from the poem itself that the lover wins the battle or not but from threw wild hands towards the sky and affrighted steed ran on alone, we are shown the melodramatic image of death. In some conditions, throwing hands towards the sky can be defined as victory despite the death of the soldier in the war, but the word wild gives some sense of vague idea whether his death is worthy or not for the battle. The word steed which means warhorse, ensures that the lover is a soldier, while affrighted and ran on alone certify that the lover has fallen from the steed and the affrighted steed ran alone, possibly because of the sound of gun or explosion, leaving the soldier behind.

Generally, this first stanza can be seen as a depiction of the emotional loss of the maiden. The effect of do not weep and war is kind arouses the sympathy for the victims of war, which is the maiden (in this stanza). This stanza is sarcastic about the purposes of war, of the victory whose worthiness is still questionable. The dying soldier who has fallen from his war horse shows the reality of death on the battlefield, while the maiden who is told to be tough because of the death of her lover shows the torture and suffers which is felt by those who are left by their lovers in the battle.

The second stanza presents other images and statements about war. The first line of the second stanza, 'Hoarse, booming drums of the regiment,' attracts the reader's sense of hearing. The phrase booming drums of the regiment shows the vigor of war. The word regiment ensures the reader that the war which is being talked about here is somehow great and involves a large number of people. The second line, 'Little souls who thirst for fight,' gives the image of dreadful soldiers. The word little souls emphasize the horrifying image of soldiers because here in the poem, the military soldiers are portrayed as people who are heartless, while the phrase thirst for fight shows the atrociousness of the soldiers, meaning that these soldiers have a great desire to fight others and engage in a battle, and it makes them relieved from the thirst.

The next two lines confirm the image of dreadful soldiers which is shown in the previous lines in this stanza. The line 'These men were born to drill and die,' confirms that the soldiers are destined to give everything to the war. They are trained to be men of war and meant to die in the worth of war. They should be ready to die at anytime during the war. 'The unexplained glory flies above them,' underscore the pointlessness of war and also the ridiculousness of the military. The word unexplained glory means vain, irrational meaning of victory in war. The soldiers fight for something that they do not really understand. They are willing to give their lives in reaching this fake glory and pride, meaning that the glory and pride which are obtained by killing peo- 
ple and making destruction is worthless. This relates to the previous line where the soldiers are portrayed as little souls.

In the next two lines, 'Great is the BattleGod, great, and his Kingdom - A field where a thousand corpses lie,' shows the senselessness of war. The word great can be interpreted as pride. The soldiers are controlled by this meaningless concept. Pride here is something that makes them wants to sacrifice their lives in the war, proud of themselves as soldiers who fight for their own purpose and also pride for being in the battle in the name of their Kingdom which can be interpreted as nation or side which they stand for. While the phrase field where a thousand corpses lie emphasizes the shocking loss of the war. A thousand corpses shows us the image of futile death as the consequence of war.

The subject of misery in the third stanza is the babe whose father has died in the war. This stanza begins with 'Do not weep, babe, for war is kind.' Similar to the opening line of the poem, its function is to give the ironic tone to the poem. Once more, despite the fact that war has offered so many deaths and losses to lots of people who are involved in the war which has been described in the previous stanza, war is still somehow "kind" in this stanza.

The next two lines describe how the father of the babe died in the war. 'Because your father tumbled in the yellow trenches Raged at his breast, gulped, and died.' These two lines show another image of death. The phrase yellow trenches describes the setting of the war itself, especially the place where the father died. These trenches are usually made for defensive structure to protect soldiers from any bullet or attack of the enemy, while at the end of war, these are used to bury corpses or dead bodies.

It tells us about the father who is involved in the war and died in the battle. $\mathrm{He}$ is enraged by the battle, just like other people who are involved in a war, however he dies because of his rage. The word gulped shows that this rage was unclear, meaning that mostly in war, soldiers are raging to kill or to be killed. When soldiers are lost in rage, they will lose control and make themselves to be contemptible. Finally, it was just futile deaths.

Yet, the effect of do not weep and war is kind is still arousing sympathy for the victims of war, which is the babe in this stanza, and to be cynical about the stupidity of war, of the death which is caused by unreasonable rage, a foolish anger which is caused by a ridiculous reason of war.

The fourth stanza presents another image of the soldiers. In the first line, 'Swift blazing flag of the regiment' creates the atmosphere of war. The phrase swift blazing flag shows the spirit of war, while the word regiment shows that it is a massive war where there are lots of soldiers involved in the war.

In the second line, 'Eagle with crest of red and gold' shows the courage of the soldier at war. The word eagle symbolizes bravery and courage, while red and gold are colours that represent the crown and empire.

In the third line, 'These men were born to drill and die' presents us the image of contemptible soldier who are destined to kill and be killed. The word drill itself can be interpreted as work or train hard to be a great soldier, sacrificing all of their lives to be at war. While in the fourth line 'Point for them the virtue of slaughter' shows that the soldiers are foolish because they are just like statues who are shaped by evil. The word the virtue of slaughter shows that war contains lots of malice where people are slaughtering each other. The word virtue is used as the irony to show that it has no morality at all.

In the fifth line, 'Make plain to them the excellence of killing' shows another malice of war where killing others has a great value. The word the excellence of killing itself shows that in a war, everything about death is normal, even worse death is a must. When two 
sides are fighting in a war, there must be death on one side or death for both sides. The word excellence is used as another irony to state that killing does not have any decent quality. The last line of this stanza is a repetition of the last line in the second stanza. It emphasizes the massive loss which is caused by the war.

The subject of misery in the last stanza is the mother whose son dies in the war. The first and the second line of the stanza, 'Mother whose heart hung humble as a button, On the bright splendid shroud of your son' shows the misery which is felt by the mother. The mother waits for her son in the war with worry but at the end she finds that her son is dead.

The word humble means showing a consciousness of one's defects or shortcoming, not proud, not self-assertive, and modest. The phrase humble as a button here means that the mother is watching silently or wordlessly, not howling or crying, on the shroud of her son. It gives the impression that the death which is caused by war is a mistake and this son of the mother has to take the burden.

The phrase bright splendid shroud shows another irony in the poem. A death shroud, which is a piece of fabric that a dead person's body is wrapped in before it is buried, should not be bright and splendid. In other way of saying, the honor of a glory in the war means nothing for the mother though her son is covered with a fine quality of shroud. The effect of the use of word 'your' is to produce the reader's sense of being in the possession of a mother who loses her son as the consequence of war deficiency.

\section{B. Dirge for Two Veterans by Walt Whitman}

The first stanza describes the setting of time in the poem which is in the dusk of Sabbath and the setting of place in the poem which is on the pavement. The first line 'the last sunbeam' shows that the time setting of the poem is in the dusk. Then in the next line, the word Sabbath means the day of rest which was originally the seventh day of the week. So from this two lines, 'The last sunbeam lightly falls from the finish'd Sabbath,' can be interpreted as a day of rest when people prepare themselves for something which is going to happen at the beginning of the following week, which is war in this context.

The third and fourth line of the stanza, 'On the pavement here - and there beyond, it is looking, down a new-made double grave' show that there is a new-made double grave that can be seen from the pavement. The word new-made here shows that the grave has just been made, while the word double grave is associated with the title, Dirge for Two Veterans, meaning that the double grave is the burial place for the two veterans who died in the war.

In the second stanza, the repetition of moon is appealing. It completes the setting which is described in the previous stanza, which is in the night time. The image of "the moon ascending', meaning a moon which is moving upward and become brighter in the dark, emphasizes the setting of time in the poem. The moon is depicted as silvery round, beautiful, ghastly, immense, and silent. Although the moon is big and beautiful but it still arouse the sense of misery in the word ghastly and silent. It shows a dismal nightmare, creating fright and dread which is caused by the death.

In the third and fourth line of the stanza, 'Beautiful over the house tops, ghastly phantom moon; immense and silent moon,' the moon shows the emotion which is strong and able to shine despite the misery which is felt and seen. It shows tenderness but also tries to remain tough so that the next day can be defied. The phrase ghastly phantom moon gives emphasis to the fright of the death. Ghastly means horrifying, involving suffering or death, while phantom means ghost or something which is especially in a human form, 
which you think you see or hear but it is not real.

In the third stanza, the narrator arouses more on our sense of hearing. The narrator sees a sad procession, which is the funeral procession of the two veterans. In the second line, 'And I hear the sound of coming full-key'd bugles' shows that it is a military funeral procession. The bugle is a wind instrument which is mostly without keys or valves, consisting of a seamless tube of metal and it is used for sounding military signal or in military bands. The word full-key'd means loud.

Then in the third and fourth line, "All the channels of the city streets they're flooding, as with voices and with tears' emphasizes that the sound of the instrument is very loud and can be heard in all of the city channels, meaning that the funeral is very miserable and affects an extensive range of area. The word they here refer to the sounds which are produced by the bugles. These flooding sounds of bugles are also accompanied with voices and tears of sorrow, creating an immense miserable atmosphere. The funeral procession of the veterans has a great effect, causing the people who see and hear it to have a dismal feeling.

The fourth stanza intensifies the atmosphere created in the previous stanza. In the first and second line of the stanza, 'I hear the great drums pounding, and the small drums steady whirring,' shows another marking out of the funeral procession itself. In the military funeral procession, there are a lot of instruments which are played together to signal a funeral procession which are being marched and drums are included in them.

In the third and fourth line of the stanza, 'and every blow of the great convulsive drums, strikes me through and through,' shows that the death haunts the narrator's mind. Every blow of the great convulsive drums strengthens the mourning which is felt by the narra- tor. With every blow of the drums, he feels the grief caused by the death of the two veterans.

The fifth stanza shows that the subject of the poem is the two veterans. They are the son and his father. In the first and second line, 'For the son is brought with the father; In the foremost ranks of the fierce assault they fell,' shows that they were being together in the war but died in a ferocious attack when they were fighting against the enemy in the front line. The phrase foremost ranks shows that these two veterans are the frontliners, meaning that they are just an ordinary soldier and their position in the troops is in the front of the barricade. Frontliners are the first troops to be killed in the war.

In the third and fourth line, 'Two veterans, son and father, dropt together, and the double grave await them,' confirms the death of these two veterans. The words dropt together mean that they are not separated from each other in the assault and died together as brave soldiers. The words double grave intensifies the deep grief which is felt because it is not just two strangers dying at the same time but a father and a son who fights and dies together in the war, causing more pain to the bereaved family and friends.

In the first and second line of the sixth stanza, 'Now nearer blow the bugles, and the drums strike more conclusive,' shows the narrator's agony about the death. The sound of bugles and drums coming closer to the narrator means that the demise of the son and his father is bothering the narrator's mind because the funeral procession is coming through and it creates an appalling fear of death.

In the third and fourth line of the stanza, 'And the day-light o'er the pavement quite has faded, and the strong dead-march enwraps me,' confirms the narrator's agony in the previous lines of the stanza. The day-light which has faded means that the narrator starts to 
be sorrowful, while being enwrapped or surrounded by the strong dead-march means that this sad funeral procession haunts the narrator.

In the first and second line of the seventh stanza, 'In the eastern sky up-buoying, the sorrowful vast phantom moves illumin'd,' shows that the moon becomes clearer and buoying up high. The word buoying means floating or can be interpreted as getting an encouragement to move on from that misery though the atmosphere is still gloomy. The sorrowful vast phantom represents the moon, and it has become illuminated which can be interpreted that the anguish is real and somehow the people involved in this situation have to deal with it.

In the third and fourth line of the stanza, '(Tis some mother's large, transparent face, in heaven brighter growing,)' shows that there is a grace in the death of the two veterans. It is shown by the transparent image of a mother's face which is shining brightly. The narrator realizes that the son and his father's soul will be content together in heaven because they are two valiant heroes.

The eighth stanza can be seen as the narrator's consciousness and it is emphasized by the exclamation marks. In the first line of the stanza, 'O strong dead-march, you please me!' shows that the narrator finally realizes that the funeral procession has given him strength to face the death and it is very pleasing. Then in the next line of the stanza, 'O moon immense, with your silvery face you soothe me!' shows that the narrator can finally ease with the fear and fright.

The third and fourth line of the stanza, 'O my soldiers twain! O my veterans, passing to burial! What I have I also give you,' shows that the narrator has been able to accept the death of the two veterans that are passing to be buried. The narrator gives his love and respect to honor the death of the two veterans.

The last stanza of the poem tells about the narrator's solace after all. The moon is shining, the bugles and the drums are playing in respect of the son and his father for dying honorably at war. The narrator is affected by these objects so that the narrator can finally accept the death of the two veterans and praise them for their death in the war with love from his heart.

\section{CONCLUSION}

Based on the analysis of the two poems, it can be concluded that the misery which is caused by the war exists and affects so many people. Both Stephen Crane's War is Kind and Walt Whitman's Dirge for Two Veterans provide us with the images of death and misery that are caused by the war though in slightly different ways. Stephen Crane's War Is Kind talks about the theme of war in the Spanish-American War era while Walt Whitman's Dirge for Two Veterans talks about the same theme in the American Civil War era. Although these two poems have the same theme, each of the poems has its own characteristic in expressing the misery that is caused by the war.

War is Kind highlights the irony of 'war is kind' to provoke the sense of dreadfulness. By using this irony, it tries to influence the readers to judge that war is not kind at all. Dirge for Two Veterans also points out death as the consequence of the war. But in this poem, misery is described as something that should be endured though it is haunting and frightening.

Generally, these two poems warn people about the misery of war. Though the way the poem illustrates the misery of war is different, they have the same viewpoint about war. War is evil and cruel. It brings destruction, suffering, sadness, and sorrow to many people. People are supposed to share the world and live in peace. War is a waste of time and worthless. There are so many things that are more precious that the "glory" in war which causes destructions and deaths. 


\section{A. War is Kind}

Do not weep, maiden, for war is kind. Because the lover threw wild hands toward the sky

And the affrighted steed ran on alone, Do not weep.

War is kind.

Hoarse, booming drums of the regiment, Little souls who thirst for fight, These men were born to drill and die. The unexplained glory flies above them, Great is the Battle-God, great, and his Kingdom -

A field where a thousand corpses lie.

Do not weep, babe, for war is kind.

Because your father tumbled in the yellow trenches,

Raged at his breast, gulped, and died,

Do not weep.

War is kind.

Swift blazing flag of the regiment, Eagle with crest of red and gold, These men were born to drill and die. Point for them the virtue of slaughter, Make plain to them the excellence of killing And a field where a thousand corpses lie.

Mother whose heart hung humble as a button On the bright splendid shroud of your son, Do not weep.

War is kind.

\section{B. Dirge for Two Veterans}

The last sunbeam

Lightly falls from the finish'd Sabbath,

On the pavement here - and there beyond, it is looking,

Down a new-made double grave.

Lo! The moon ascending!

Up from the east, silvery round moon;

Beautiful over the house tops, ghastly phantom moon;

Immense and silent moon.

I see a sad procession,
And I hear the sound of coming full-key'd bugles;

All the channels of the city streets they're flooding,

As with voices and with tears.

I hear the great drums pounding, And the small drums steady whirring;

And every blow of the great convulsive drums, Strikes me through and through.

For the son is brought with the father;

In the foremost ranks of the fierce assault they fell;

Two veterans, son and father, dropt together, And the double grave awaits them.

Now nearer blow the hugles, And the drums strike more conclusive;

And the day-light o'er the pavement quite has faded,

And the strong dead-march enwraps me.

In the eastern sky up-buoying,

The sorrowful vast phantom moves illumin'd; ('Tis some mother's large, transparent face, In heaven brighter growing.)

O strong dead-march, you please me!

O moon immense, with your silvery face you soothe me!

O my soldiers twain! O my veterans, passing to burial!

What I have I also give you.

The moon gives you light,

And the bugles and the drums give you music; And my heart, $\mathrm{O}$ my soldiers, my veterans, My heart gives you love.

\section{BIBLIOGRAPHY}

Abrams, M.H. A Glossary of Literary Terms. New York: Holt, Rinehart and Winston, Inc, 1971.

Abrams, M.H. The Mirror and the Lamp: Romantic Theory and the Critical Tradition. Oxford: Oxford University Press, 1971.

Culler, Jonathan. Structuralists Poetics: Structuralism, Linguistics, and the Study of Literature. London: Routledge \& Kegan Paul Ltd, 1975. 
Hornby, A.S. Oxford Advanced Learner's Dictionary. Oxford: Oxford University Press, 1995.

Kaplan, Justin. Walt Whitman: Complete Poetry and Collected Prose. Cambridge: Library of America, 1982.

Katz, Joseph. The Complete Poems of Stephen Crane. Michigan: Cornell University Press, 1972.

Microsoft Encarta Encyclopedia Deluxe 2002

Reaske, Chistopher Russell. How To Analyze Poetry. New York: Monarch Press, 1966.

Webster, A. Merriam. The Merriam Webster Pocket Dictionary. New York: Pocket Book, 1947.

Whitman, Walt. Leaves of Grass. New York: Bantam Books, 1983.

Merriman, C.D. Biography. Jalic Inc. 2007

$<$ http://www.online-literature.com/crane>
Date of Download: August, $3^{\text {rd }} 2012$

$<$ http://www.americanpoems.com/poets/waltwhitman $>$

Date of Download: August, $7^{\text {th }} 2012$

$<$ http://www.britannica.com/topic/Spanish-American$\underline{\text { War }>}$

Date of Download: July, $20^{\text {th }} 2012$

$<$ http://www.gradesaver.com/author/stephen-crane $>$

Date of Download: August, $3^{\text {rd }} 2012$

$<$ http://www.poetryfoundation.org/bio/stephen-crane $>$

Date of Download: August, $3^{\text {rd }} 2012$

$<$ http://www.poets.org/poet.php/prmPID/126>

Date of Download: August, $8^{\text {th }} 2012$

$<$ http://www.vetshome.com/spanish-american-war. $\underline{\mathrm{htm}>}$

Date of Download: July, $22^{\text {nd }} 2012$ 